$\begin{gathered}\text { EPiC Series in Education Science } \\ \text { Volume 1, 2017, Pages 288-296 }\end{gathered}$
$\begin{gathered}\text { AUBEA 2017: Australasian Universities Build- } \\ \text { ing Education Association Conference 2017 }\end{gathered}$

\title{
Understanding the Benefits of Constructing a Residential House with a Heart of Cold-Formed Steel
}

\author{
Vidal P. Paton-Cole ${ }^{1}$ and Emad F. Gad ${ }^{2}$ \\ ${ }^{1}$ University of Melbourne, Melbourne, Australia \\ ${ }^{2}$ Swinburne University of Technology, Hawthorn, Australia \\ vidalpc@unimelb.edu.au, egad@swin.edu.au
}

\begin{abstract}
Constructing residential houses with cold-formed steel in Australia dates back to the 1940 's when there was a shortage of timber for use in the industry. This subsequently led to the formation of the National Association of Steel-Framed Housing (NASH) in 1982 with the objective of promoting the use of cold-formed steel in the construction industry, in particular for application to construction of low-rise residential houses. Over the last few decades, NASH has made significant progress in promoting steel and has led to the inclusion of steel-framed housing in the Building Code of Australia (BCA) and the development of a standard on residential and low-rise steel framing. Conventional detached housing is the largest single form of residential construction in Australia with approximately 120,000 built in 2015 . Therefore, the safety, durability, performance and long-term low operational costs over the 50-year design life of a typical residential house are of significance. Constructed residential houses satisfying these requirements would not only translate to significant savings to homeowners personally but also to the nation. This paper discusses the benefits of using cold-formed steel for constructing low-rise residential structures. Based on a full-scale experimental study that was undertaken to assess the overall performance of a brick veneer steel-framed structure, the performancebased requirements of residential houses built of cold-formed steel framing are evaluated and discussed.
\end{abstract}

\section{Introduction}

In Australia and New Zealand, the most common form of residential construction is "brick veneer" single or double storey houses, generally referred to as "light framed construction". These domestic houses and construction form are also warmly embraced in the United States and Canada. Brick veneer form of construction consists of a wall system that has a flexible structural frame (timber or steel) that 
supports an external skin of brick wall. The wall serves the purpose of cladding only and offering no form of structural support. Brick ties serves as the connecting component in the wall system tying the external skin of brick wall and the load bearing structural frame. When the structure is subjected to any form of imposed loads, it is expected that the brick wall transfer these loads to the load-bearing frame via the brick ties. Internally, the structural frame is often complete with plasterboard lining which forms an aesthetic pleasing internal finish to the walls.

Traditionally, timber has been the most common structural frame used for the construction of light framed houses in Australia. It was not until the 1940's when the Australian building industry experienced significant shortage of timber (Hancock and Murray, 1996; NASH, 2009a) that the use of cold-formed steel framing systems was introduced for the construction of domestic houses and has since proved as a viable alternative. While the use of cold-formed steel framing for light framed construction in Australia has been successful in terms of performance, at its inception stages, its introduction into the building construction industry faced some difficulties. Cold-formed steel had no standard design available at the time and was not part of the Building Code of Australia. This initially inhibits recognition of the products by building practitioners. These challenges were alleviated by the formation of the National Association of Steel House Framing (NASH) in 1982, with the objective to promote the use of cold-formed steel for residential houses and further support growth, develop educational and training programs for industry practitioners. To date, NASH have developed numerous design guides including a handbook for the Design of Residential and Low-rise Steel Framing (NASH, 2009). NASH have also satisfactorily provided testing and documentation on the performance requirements for coldformed steel framing that have led to its inclusion in the Building Code of Australia (ABCB, 2006). Whence, the innovative use of steel framing has evolved over the years, continually used for construction of residential houses in Australia and have become popular with industry practitioners.

\section{Cold-Formed Steel Framing}

Cold-formed steel framing sections used for framing components in residential houses in Australia are fabricated from steel that complies with AS 1397, 2001. The components are typically from steel designated as G550 galvanised steel sections (AS1397, 2001). The G gives an indication of the mechanical properties while the 550 represents the yield stress of the steel in Megapascals (MPa). The high strength and ductility of cold-formed steel frames complemented with their robust riveted connections makes them ideal for the construction of domestic houses in areas of high wind speed like Queensland. Such houses are also expected to perform extremely well when constructed in seismic regions like New Zealand (Bruneau et al., 2010; Clifton et al., 2011; Paton-Cole et al., 2012; PatonCole, 2014). Cold-formed steel frames offer many advantages such as dimensionally stable, high strength and stiffness, lightweight, easy prefabrication, mass production, easy erection and installation and $100 \%$ recyclable. In addition, they are termite resistance, non-combustible and generally easy to transport. The galvanisation of cold-formed steel sections (AS1397, 2001) protect the material against corrosion, which means they can last for many decades and reducing long term maintenance costs. As cold-formed steel frames are often prefabricated assemblies, they offer uniform quality with shorter construction times and reduced wastage. In a recent study conducted to evaluate the potential of waste reduction through offsite construction (WRAP, 2008), it was concluded that the offsite production of cold-formed steel frames is an exemplar to highlight waste minimisation.

Cold-formed steel application goes beyond residential construction and commonly used for internal partitions and infill panels for commercial, educational and industrial buildings. In Australia, coldformed steel is increasingly being used for multi-storey apartment buildings and has popularly been 
used for medium rise residential buildings in the United States. The numerous advantages offered by cold-formed steel have resulted in extensive application in both commercial and residential projects in the United States, with hundreds of thousands of residential houses built over the last two decades (SFA, 2007). For residential constructions in the UK, cold-formed steel framing techniques are often used for single occupancy dwellings, medium rise and multi-occupancy buildings (WRAP, 2008). Conventional detached housing is the largest single form of residential construction in Australia with approximately 120,000 built in 2015 as reported by the Australian Bureau of Statistics. A significant percentage of these houses were built using cold-formed steel structural framing in a typical brick veneer construction form as shown in Figure 1 for a detached house.

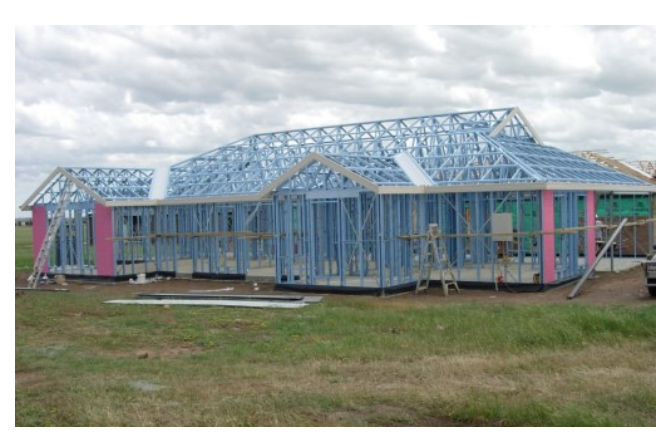

(a)

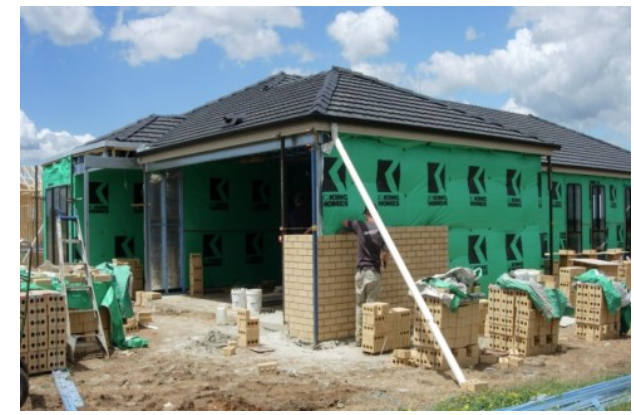

(b)

Figure 1: (a) Residential house framing with cold-formed steel; (b) Brick veneer house built with coldformed steel

To better understand the behaviour and evaluate the performance of cold-formed steel frames, numerous studies has been undertaken to evaluate and establish the structural adequacy and performance of full scale houses built with cold-formed steel (Barton, 1997; Gad, 1997; Paton-Cole et al., 2011; Paton-Cole, 2014). All these studies reported exceptional performance of the tested coldformed steel elements, with all test results surpassing stipulated code requirements. Other studies have also been conducted to investigate the behaviour of these structures under fire conditions (Pantham and Clifton, 2014) with an exceptional performance reported.

In the past, cold-formed steel was not competitive with traditional timber framing due to the basis of cost, manufacturing capability and trades acceptance. However, due to recent industrialised innovation in cold-formed steel production like the FRAMECAD "factory in a can" manufacturing technology (FRAMECAD, 2009), the use of cold-formed steel in residential construction has gained increased popularity in Australia and New Zealand while being cost-competitive to traditional framing methods. With recent advances in manufacturing techniques, cold-formed steel manufacturers are continually improving a variety of sections and connections in order to produce more cost competitive products. NASH further provides educational and training programs for industry practitioners as well as developing and maintaining design standards for cold-formed steel. These developments have enhanced the confidence of industry practitioners to employ the use of cold-formed steel in a variety of applications. The recent inclusion of the NASH standard in the National Construction Code (ABCB, 2006) has made it easier to specify and design residential houses using cold-formed steel. The deemed to satisfy requirements detailed in the standard streamlines the design, detailing and construction processes. 
Understanding the advantages and benefits cold-formed steel framing has to offer, there is the potential to construct exceptionally safe and efficient residential houses. Significant failure and likely collapse of structures in particular during natural disasters or fire is not only life threatening, the economic losses and disruption to amenities can be great. Therefore, the safety of residential houses is not just important at a personal level but of benefit to the community and a nation as a whole. With the thousands of residential houses built across Australia every year, the economic savings from using coldformed steel framing would be enormous with better-expected performance of such houses once in service.

\subsection{House Framing Components}

Residential houses built of cold-formed steel consists of three major components namely floor framing, wall framing and roof framing units as described in the following sections. The concept of using cold-formed steel for residential house construction is to use light, high strength steel sections to construct the load bearing structural frame in a configuration similar to traditional timber construction. The various framing components can be constructed by either stick framing or prefabricated panelised units. Factory precision prefabricated approach is most popularly adopted, as the finished components are straight and accurate, light and easy to transport and guarantees a faster and easier installation.

\subsection{Floor Framing}

Similar to traditional framing methods, two typical floor systems are used in constructing residential houses framed with cold-formed steel. The first of these is the "concrete slab on ground system" such as a stiffened or waffle raft footing and the second is the "suspended floor system" which constitutes a floor and subfloor system. Various proprietary systems are available for the suspended floor option and incorporates easily adjustable levelling mechanisms that makes them very easy to install and saves time. NASH general guide (NASH, 2009a) and Handbook (NASH, 2009) provides comprehensive details of the various systems including hold down connection details.

\subsection{Wall Framing}

Walls framed with cold-formed steel members in residential construction consist of components such as studs, noggings, top and bottom plates and wall bracings. The walls are designed as either load bearing or non-load bearing walls. A variety of stud sections are available for selection with different geometric properties and load capacities. Walls that are braced with either strap or sheet bracing resist lateral loads. External walls of cold-formed steel framed houses can be cladded with a variety of materials, though brick cladding is more popularly used in Australia due to its aesthetic appealing virtue. Internally, the wall frames are usually finished with plasterboard lining. NASH Handbook (NASH, 2009) provides comprehensive details of the available framing options and connection details that can be used for construction.

\subsection{Roof Framing}

The roof structure of a residential house framed with cold-formed steel sections generally consist of roof trusses that are fabricated in different shapes and sizes. The roof cladding can either be of steel sheeting or roof tiles and the nature of the roof structure is significantly influenced by the type of roof cladding used. Roof battens that are laid over the roof trusses generally support the roof cladding. The roof structure is generally braced to ensure the roof resist imposed loads as a single unit. Internally, the ceiling-framing members once lined with traditional plasterboard provides a diaphragm action that enhances the stability of the entire roof structure. 


\section{Experimental Testing}

To assess the overall performance of a structure built out of cold-formed steel, a Test House was designed for a comprehensive shaking table test program. A shaking table is used to simulate artificial earthquake and a test of this nature would represents one of the worst conditions to which a structure would be subjected to during its service life. As shown in Figure 2, the Test House was a full-scale single-room structure replicating typical construction practice of a steel-framed brick veneer house as built in New Zealand. It measured approximately $2.6 \mathrm{~m}$ x $2.8 \mathrm{~m}$ x $2.4 \mathrm{~m}$ high. The Test House comprised of steel frame walls and ceiling with brick veneer cladding and plasterboard lining, fully constructed using typical full-scale components. The framing and bracing members were made of $0.75 \mathrm{~mm}$ G550 Z275 galvanised steel sections (AS1397, 2001). All the framing connections between plates, studs, noggings and bracing were screwed connections in compliance with the NASH Handbook (NASH, 2009).

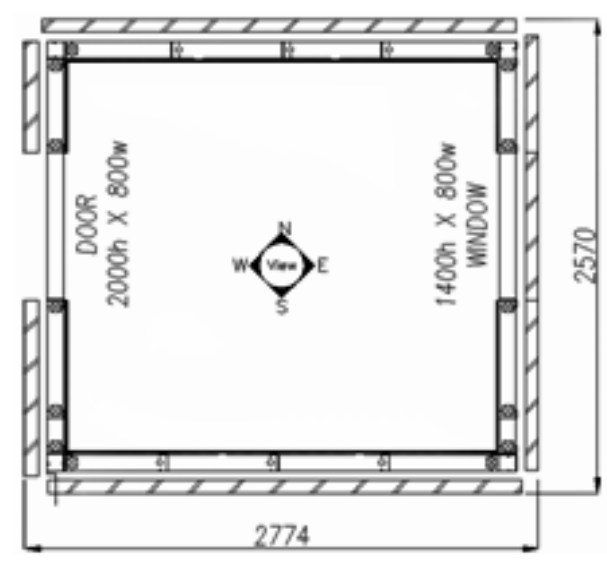

(a) Plan of Test House

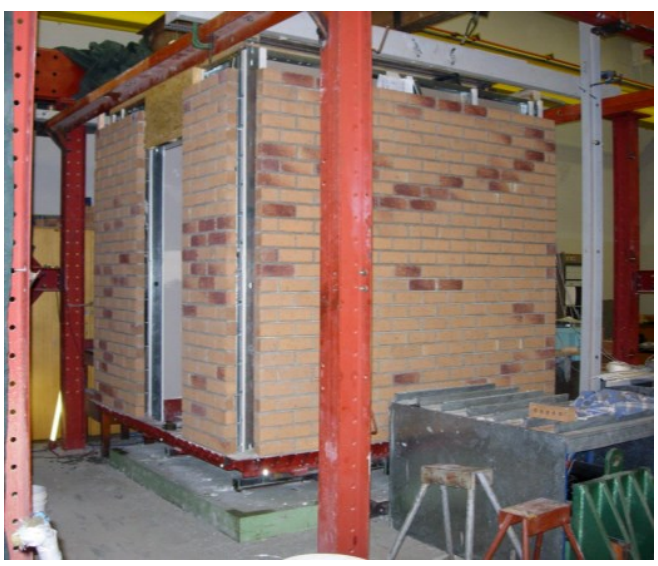

(b) Completed Test specimen

Figure 2: Geometry of Test specimen

The brick veneer walls were constructed using standard New Zealand 70 series clay brick units measuring $230 \mathrm{~mm} \times 70 \mathrm{~mm} \times 76 \mathrm{~mm}$ high with standard five core holes. The bricks were bedded with $10 \mathrm{~mm}$ thick mortar joints with a standard mix of 1:0.5:4.5. Type B Eagle brick ties were used for connecting the veneer walls to the light steel framing. Polystyrene thermal break strips $40 \mathrm{~mm}$ wide $\mathrm{x}$ $10 \mathrm{~mm}$ thick were glued to the external flange of each stud through which the tie screws were drilled. A concrete roof slab weighing $1500 \mathrm{~kg}$ was used on top of the Test House to simulate the equivalent mass from a house roof. Walls and ceiling were lined with $10 \mathrm{~mm}$ thick plasterboard and secured with screws.

To assess the performance of the Test House against specific design performance criteria, a design earthquake was selected as input excitation to the shaking table. The selected excitation was the 1940 El-Centro (ELC) earthquake that is compliant with the New Zealand Earthquake Loading Standard (NZS1170.5, 2004). The specific levels of excitation that were targeted are listed in Table 1. To evaluate the Test House performance, displacements and accelerations were measured at numerous locations on the Test House using Linear Voltage Displacement Transducers (LVDTs) and uniaxial accelerometers respectively. Webcams were installed at strategic locations to monitor the relative movement between the structural frame and veneer through the cavity. 


\begin{tabular}{ccl}
\hline $\begin{array}{c}\text { Earthquake design } \\
\text { level }\end{array}$ & $\begin{array}{c}\text { Scale relative to } \\
\text { El-Centro }\end{array}$ & \multicolumn{1}{c}{ Required performance limits } \\
\hline $\begin{array}{c}\text { Serviceability Limit } \\
\text { State (SLS) }\end{array}$ & 0.89 El-Centro & $\begin{array}{l}\text { Localised hairline cracking of veneer and } \\
\text { lining at most vulnerable locations. No post- } \\
\text { earthquake remedial work required. }\end{array}$ \\
$\begin{array}{c}\text { Ultimate Limit State } \\
\text { (ULS) }\end{array}$ & 1.28 El-Centro & $\begin{array}{l}\text { Noticeable cracking of veneer and linings, } \\
\text { brick loss limited to }<5 \% \text { of bricks or the top } \\
\text { two rows above the top row of ties. Visible } \\
\text { damage to frame expected but not to be } \\
\text { significant and not to reduce ability of frame } \\
\text { to support house. }\end{array}$ \\
$\begin{array}{c}\text { Maximum Considered } \\
\text { Earthquake (MCE) }\end{array}$ & 1.72 El-Centro & $\begin{array}{l}\text { Significant linings and framing damage but } \\
\text { no collapse of framing. Significant brick loss. }\end{array}$ \\
\hline
\end{tabular}

Table 1: Earthquake levels adopted for testing and corresponding performance criteria

\subsection{Experimental Results}

The Test House was subjected to progressively increasing ground excitation along the two principal axes of the house considered as North-South and East West directions as shown in Figure 2. A summary of the testing sequence and observations made after each test are presented in Table 2. The Test House performed very well in both directions of shaking up to MCE level earthquake as described in Table 2. The Test House performance is considered to be exceptionally good at this intensity of shaking in comparison to the performance criteria outlined in Table 1. With no evidence of significant damage on the Test House after applying MCE in each direction, the selected input excitation was further scaled increasingly to impose more severe shaking. Up to 2.6 times ELC no bricks were lost or any significant damage occurred in the North and South brick veneer walls. This is extremely good performance given the fact that the Test House had already been subjected to 7 high level earthquakes prior to 2.6 times ELC. It is considered impossible for a single house to experience this number and severity of earthquakes during its design life. At the end of 2.6 times ELC, a partial failure of the connection between the top diagonal bracings and top plates on both East and West walls was noticed but no bricks loss or tie pullout observed.

At the end of the test at 2.7 times ELC, a complete connection failure occurred at the ends of the top diagonal bracing in both East and West walls. Despite the very large displacement of the frame, the brick ties did not separate from the studs or the veneer in the North and South walls. This reflects a high degree of resistance and robustness of the connections of the ties at both the stud end as well as the veneer end. Based on visual observations, the connectivity between the veneer walls and the frame were maintained throughout the test with no ties disengaging except at the maximum level of shaking at 2.7 times El-Centro when the top two courses of bricks on the East and West walls fell off. This was due to failure at the connections of the diagonal bracing and excessive twisting of the ties on the East and West walls. 


\begin{tabular}{|c|c|c|c|}
\hline \multirow{2}{*}{$\begin{array}{l}\text { Test } \\
\text { No }\end{array}$} & \multicolumn{2}{|c|}{$\begin{array}{l}\text { Earthquake level and } \\
\text { direction }\end{array}$} & \multirow[t]{2}{*}{ Observations } \\
\hline & North- South & East- West & \\
\hline 1 & SLS & & No damage observable whatsoever. \\
\hline 2 & ULS & & $\begin{array}{l}\text { Minimal hairline cracks in the plasterboard lining at } \\
\text { window top corners. Very limited hairline cracks at } \\
\text { locations in brick veneer adjacent to opening. No } \\
\text { damage to any brick ties, the screws or the thermal } \\
\text { break. }\end{array}$ \\
\hline 3 & & SLS & No increase in damage from test 2. \\
\hline 4 & MCE & & $\begin{array}{l}\text { Minor increase in cracking of internal plasterboard at } \\
\text { window corners. No increase in cracking in brick } \\
\text { veneer. No visible damage to any ties. }\end{array}$ \\
\hline 5 & & MCE & No increase in damage from test 4 . \\
\hline 6 & $\begin{array}{l}1.16 \mathrm{MCE} \\
(2.0 \mathrm{El}- \\
\text { Centro })\end{array}$ & & $\begin{array}{l}\text { Noticeable rocking of wall brick piers at base of } \\
\text { window. Hairline cracks post test extending right across } \\
\text { pier base. No bricks lost. No visible damage to any ties. } \\
\text { No visible damage to steel framing. Plasterboard cracks } \\
\text { in window top corners now remaining open } \\
\text { approximately } 1 \mathrm{~mm} \text { after test. }\end{array}$ \\
\hline 7 & $\begin{array}{l}1.34 \mathrm{MCE} \\
(2.3 \mathrm{El}- \\
\text { Centro })\end{array}$ & & $\begin{array}{l}\text { Increased rocking and cracking during test. No new } \\
\text { cracks. No bricks lost. No visible damage to brick ties } \\
\text { but in plane twisting for the East and West walls. No } \\
\text { evidence of pullout of any ties. No visible damage to } \\
\text { steel frame. }\end{array}$ \\
\hline 8 & $\begin{array}{l}\text { 1.51MCE } \\
(2.6 \mathrm{El}- \\
\text { Centro })\end{array}$ & & $\begin{array}{l}\text { Partial failure of connection between the top of diagonal } \\
\text { brace and top plate for East and West walls. No bricks } \\
\text { lost. No tie pullout from frame or veneer. }\end{array}$ \\
\hline 9 & $\begin{array}{l}\text { 1.57MCE } \\
(2.7 \mathrm{El}- \\
\text { Centro })\end{array}$ & & $\begin{array}{l}\text { Failure of connection of diagonal brace to top plate in } \\
\text { East and West walls. Top } 2 \text { rows of bricks lost in East } \\
\text { and West walls. No bricks lost from the North and South } \\
\text { walls. Minimal to no damage to ties in the North and } \\
\text { South walls. No tie pullout from studs in any location. }\end{array}$ \\
\hline
\end{tabular}

Table 2: Summary of tests performed and observations made 


\section{Conclusions}

Light framed domestic structures are predominantly used for residential purposes in many countries including Australia and New Zealand. The use of cold-formed steel framing for constructing these houses has gained significant attention by industry practitioners due to the numerous advantages steel has to offer. As cold-formed steel have become quite cost competitive in recent times, it can provide the economic platform for constructing low maintenance residential houses with better-expected performance. Tradesmen that are familiar with timber framing methods can adapt fairly easily to coldformed steel material and NASH provides the required education and training programs for industry practitioners.

A Test House constructed of high-strength cold-formed steel frame with brick veneer cladding and plasterboard lining was tested under earthquake loads to assess the performance of a typical structure when subjected to extreme loading conditions. Given that the Test House was designed using conventional methods, constructed from typical components and built using standard techniques it would be considered to be representative of brick-veneer light steel framed construction. With its excellent performance under an extremely onerous earthquake testing program, it can be concluded that such a form of construction would be expected to perform very well in high wind and seismic areas. Based on the test results presented in this paper, it can be concluded that houses built with cold-formed steel framing would perform exceptionally well in disaster prone areas in Australia, where a robust structure of this nature is required. Hence, with the advantages and benefits cold-formed steel framing has to offer, there is the potential to construct exceptionally safe and efficient residential houses.

\section{References}

ABCB (2006). National Construction Code Series Volume 2, Building Code of Australia 2006, Class 1 and 10 Buildings. Canberra, Australia: Australian Building Codes Board.

AS1397 (2001). AS1397. Steel sheet and strip - Hot-dipped zinc coated or aluminium/zinc-coated. NSW, Australia: Standards Association of Australia.

Barton, A.D. (1997). Performance of steel framed domestic structures subjected to earthquake loads. Ph.D Thesis, The University of Melbourne.

Bruneau, M., Anagnostopoulou, M., MacRae, G., Clifton, C. \& Fussell, A. (2010). Preliminary Report on Steel Building Damage from the Darfield (New Zealand) M7.1 Earthquake of September 4, 2010. Bulletin of the New Zealand Society for Earthquake Engineering, 43, 351-359.

Clifton, C.G., Bruneau, M., MacRae, G., Leon, R. \& Fussell, A. (2011). Steel Building Damage from the Christchurch Earthquake Series of 2010/2011. Structural Engineering Society New Zealand, 24, 27-42.

FRAMECAD (2009). Framecad mobile factory. Australia: Framecad Solutions.

Gad, E.F. (1997). Performance of brick-veneer steel-framed domestic structures under earthquake loading. Ph.D Thesis, The University of Melbourne.

Hancock, G.J. \& Murray, T.M. (1996). Residential applications of cold-formed structural members in Australia. 13th International Specialty Conference on Cold-Formed Steel Structures, October 1718, 1996. Missouri, USA, pp 505-511.

NASH (2009). NASH Handbook: Design of Residential and Low-rise Steel Framing. Manukau City, New Zealand: National Association of Steel-Framed Housing Incorporated.

NASH (2009a). General guide to Steel-Framed Building. VIC, Australia: National Association of Steel-Framed Housing Incorporated. 
NZS1170.5 (2004). NZS1170.5. Structural Design Actions Part 5: Earthquake actions - New Zealand. Wellington, New Zealand: Standards Association of New Zealand.

Pantham, R. \& Clifton, G.C. (2014). Fire Engineering Investigation of a Cold Formed Steel Framed House Fire. New Zealand: University of Auckland.

Paton-Cole, V.P. (2014). Out-of-plane dynamic response behaviour of brick veneer steel-framed walls. Ph.D Thesis, The University of Melbourne.

Paton-Cole, V.P., Gad, E.F., Clifton, C., Heath, D.J., Davies, C., Hicks, S. \& Lam, N. (2011). Dynamic performance of a brick veneer house with steel framing. Australian Journal of Structural Engineering, 11, 231-242.

Paton-Cole, V.P., Gad, E.F., Clifton, C., Lam, N.T.K., Davies, C. \& Hicks, S. (2012). Out-of-plane performance of a brick veneer steel-framed house subjected to seismic loads. Construction and Building Materials, 28, 779-790.

SFA (2007). A builder's guide to steel frame construction Steel Framing Guide. Washington DC, USA: Steel Framing Alliance.

WRAP (2008). Waste Reduction Potential of Light Steel Frame Construction. WAS 003-003: Offsite Construction Case Study. Oxfordshire, UK: Waste \& Resources Action Programme. 